\title{
The career youth pastor: A contemporary reflection
}

\begin{tabular}{|c|c|}
\hline \multicolumn{2}{|c|}{$\begin{array}{l}\text { Authors: } \\
\text { Garth Aziz }{ }^{1} \\
\text { Malan Nelº } \\
\text { Ronnie Davis }\end{array}$} \\
\hline \multicolumn{2}{|c|}{$\begin{array}{l}\text { Affiliations: } \\
{ }^{1} \text { Department of Philosophy, } \\
\text { Practical and Systematic } \\
\text { Theology, University of } \\
\text { South Africa, South Africa }\end{array}$} \\
\hline $\begin{array}{l}{ }^{2} \text { Department } \\
\text { Theology, Un } \\
\text { Pretoria, Sou }\end{array}$ & $\begin{array}{l}\text { f Practical } \\
\text { versity of } \\
\text { h Africa }\end{array}$ \\
\hline \multicolumn{2}{|c|}{$\begin{array}{l}{ }^{3} \text { Cape Town Baptist Seminary, } \\
\text { South Africa }\end{array}$} \\
\hline \multicolumn{2}{|c|}{$\begin{array}{l}\text { Research Project Registration: } \\
\text { Project Leader: M. Nel } \\
\text { Project Number: } 02331810\end{array}$} \\
\hline \multicolumn{2}{|c|}{$\begin{array}{l}\text { Description: } \\
\text { This research is part of the } \\
\text { project, 'Congregational } \\
\text { Studies' directed by Prof. } \\
\text { Malan Nel, Department } \\
\text { Practical Theology, Faculty of } \\
\text { Theology, University of } \\
\text { Pretoria. }\end{array}$} \\
\hline \multicolumn{2}{|c|}{$\begin{array}{l}\text { Corresponding author: } \\
\text { Garth Aziz, } \\
\text { azizg@unisa.ac.za }\end{array}$} \\
\hline \multicolumn{2}{|c|}{$\begin{array}{l}\text { Dates: } \\
\text { Received: } 26 \text { Aug. } 2016 \\
\text { Accepted: } 07 \text { Feb. } 2017 \\
\text { Published: } 02 \text { Nov. } 2017\end{array}$} \\
\hline \multicolumn{2}{|c|}{$\begin{array}{l}\text { How to cite this article: } \\
\text { Aziz, G., Nel, M. \& Davis, R., } \\
\text { 2017, 'The career youth } \\
\text { pastor: A contemporary } \\
\text { reflection', HTS Teologiese } \\
\text { Studies/Theological Studies } \\
\text { 73(2), a3856. https://doi.org/ } \\
\text { 10.4102/hts.v73i2.3856 }\end{array}$} \\
\hline \multicolumn{2}{|c|}{$\begin{array}{l}\text { Copyright: } \\
\text { (C) 2017. The Authors. } \\
\text { Licensee: AOSIS. This work } \\
\text { is licensed under the } \\
\text { Creative Commons } \\
\text { Attribution License. }\end{array}$} \\
\hline \multicolumn{2}{|l|}{ Read online: } \\
\hline 口ifn & $\begin{array}{l}\text { Scan this QR } \\
\text { code with your } \\
\text { smart phone or } \\
\text { mobile device } \\
\text { to read online. }\end{array}$ \\
\hline
\end{tabular}

There has been an increase of discussion and focus on matters of theological significance in the area of youth ministry. An area that remains neglected concerns the professional youth worker in Southern Africa. This focus on professional youth work has gained a great amount of urgency from the office of the presidency of Southern Africa, who in collaboration with the Commonwealth desk have prioritised the focus on youth work in South Africa. Unfortunately, the focus on the professional youth worker, the career youth pastor, within the church in Southern Africa fails to receive a similar amount of attention. The article will highlight the need to pursue a theological articulation around the office of the career youth pastor by building a practical theological argument for the office of career youth pastor. The article will address a case study of a mainline evangelical denomination regarding its theological articulation of the career youth pastor.

\section{Introduction}

The office of the youth pastor is a recent development in a South African context and is usually based upon a Western or European model. There is, however, no or little theological articulation for the office of the career youth pastor, resulting in a misunderstanding of the office of the youth pastor and a lack of efficacy in youth ministry. Furthermore, the office of the youth pastor is often seen as a transitional phase to that of the senior pastoral ministry and not regarded as a life-long career but more as the clichéd 'stepping stone' (Black 1991:18).

Youth ministry as a practical theological discipline requires adequate reflection upon its praxis and a certain amount of skill and knowledge by the practitioners for effective ministry (Nel 2005:459). It is in this context in South Africa that an emerging conversation regarding the nature and status of the professional youth worker has emerged (Commonwealth 2013; National Youth Development Agency (NYDA) 2008:7; The Presidency 2013). This conversation is further enforced by a youthful population of South Africa which exceeds 50\% (Statistics of South Africa 2012:28), and yet this very important segment of the population is facing struggles that undermine not only their economic futures but also their very identities. The concern over the welfare of the youth, however, should not remain only in the sphere of societal matters. There is a clear repercussion on the lack of discussion regarding the professional youth worker as one observes the steady decline of youth in the church.

\section{Research problem}

There is a clear lack of theological articulation of the office of the career youth pastor which has negative effects on the efficacy of youth ministry. The office of the youth pastor is often considered a temporary post that transitions one to the office of the senior pastor once substantial experience has been acquired. The article, therefore, posits the question, what supports and necessitates the need for the office of the career youth pastor?

In order to address the research problem and question, this article will focus on conceptualising the office of the career youth pastor as a professional youth worker by utilising a theoretical and qualitative empirical approach by interviewing pastors in the Baptist Union of Southern Africa (BUSA). The research is based on the apparent lack of theological articulation of the office of the career youth pastor in the BUSA. In addressing the theological articulation of the office of the career youth pastor, I propose three important aspects in conceptualising the office of the career youth pastor: firstly, a biblical foundation by observing the development of the importance of children in scripture as $\mathrm{Nel}$ (2001:13-14) argues that scripture points the way to youth ministry as God is interested in all people, including youths (Nel 2001:14; see Strong 2014:2); secondly, understanding the contemporary cultural challenges experienced by youth. In order to understand and be effective in the ministry to and with young people, one has to study and understand youth

Note: This article is published in the section Practical Theology of the Society for Practical Theology in South Africa. 
culture or the cultures that influence the lived realities of young people (Erwin 2010:18; Jacober 2011:77; Strommen, Jones \& Rahn 2001:209). The third and final aspect is grasping the importance and the relationship between adolescent identity formation and faith formation as these two concepts cannot be separated as a result of both being a means of seeking answers to existential questions (Cloete 2012:74; see Nel 2003a:156-158). Ciarrochi and Heaven (2012:676) argue that 'religious beliefs form a core component of one's personal identity'. The article, therefore, will argue that the office of the career youth pastor will add a significant addition to the contemporary discussion.

\section{A brief reflection on the history of youth ministry}

Youth ministry, which has a special and dedicated focus on children, youth and young adults (Nel 2000:8; NYDA 2008:11; Strong 2014:1), is a product of the Industrial Revolution and is in existence in its current form for barely more than a century (Senter 2001:126). Youth ministry has its origins as a cultural concept when the cultural gap between the worlds of the youth and the church increased (Senter 2001:126). It was during this time that the birth and growth of youth parachurch organisations such as the Young Men's Christian Association (YMCA), Youth with a Mission (YWAM) and Youth for Christ (YFC) (Nel 2000:55), to mention a few, took prominence and sought to attend to the needs of youth in the ever-increasing youth culture where the church was lacking or failed to make an impact. Youth ministry has almost always been evangelistic (Kageler 2004:76), as it either modelled its programmes to that of the youth parachurch organisations or by the influence of the leaders who came from these organisations. While the initial focus on the salvation of youth was facilitated through caring adult leaders, it was eventually superseded by peer-to-peer evangelism (Clark 2001:78-96). While an adult would assist with evangelism, the responsibility was almost solely left to that of the youth. Furthermore, following the evangelistic responsibility of the youth ministry, a great deal of time was spent on its teaching and discipleship programme which was ultimately part of the educational programme of the church (Clark 2001:82; Nel 2003b:63). The narrow focus of youth ministry, at the expense of evangelism and discipleship, failed to take into cognisance a holistic understanding of the lived realities of the young person.

There has been much focus in recent years on the theological nature of youth ministry, and rightly so. The historical narrative of youth ministry has often been a segmented, adhoc, separate and autonomous department of the church focusing on and utilising activity-based programmes in order to keep youth off the streets and in the church (Clark 2001:82-83). The discussion on the 'theological turn' in youth ministry has especially been brought to the fore by Root and Dean (2011), although the discussion has developed since. In a South African context, there are academics who have also begun dealing with the theological nature of youth ministry (Nel 2000). Furthermore, the discussion has also positioned youth ministry in the discipline of practical theology to affirm and legitimise it as a theological discipline worth research and study within the academy and practice. With the discussion now placing youth ministry squarely in practical theology (Jacober 2011:16; Nel 2003b:68), it has raised the importance of theological reflection and the appropriate utilisation of methodological processes and thoughts in youth ministry praxis. In the area of the theological nature of youth ministry, youth ministry as a legitimate theological practice, the ecclesiological significance of youth ministry and the purpose and mission of youth ministry, while research is limited regarding youth ministry in a South African context, empirical research remains the ideal means of addressing this lack of information (Weber 2015:5). It is in this context that this article wishes to address the neglected area of the office of the career youth pastor as a professional worker (Dean 2011:19-20) that is able to address matters that directly affect the well-being of the youth and the church's ministry to youth. The article will aim to build a legitimacy around the office of the career youth pastor by reflecting on its theological significance and articulation.

\section{A conceptual basis for the office of the career youth pastor}

The concept of the office of the youth pastor in some ways is not a new phenomenon when one considers the context in the United States. In South Africa, however, while there are churches that have youth pastors in their employ, it remains a relatively new endeavour and could be regarded to be still in its infancy. There remains much to research regarding the conceptualisation of the office of the career youth pastor in a South African context. As proposed earlier, a conceptualisation of the youth pastor will be affected by a biblical foundation, a cultural justification and adolescent identity formation.

\section{A biblical foundation}

One has to consider the prominence of youth in the Bible, the focus on specialised ministry and the qualification for pastoral ministry. While no clear or explicit scripture exists for the reasoning of youth ministry or the youth pastor, one is able to identify a development throughout scripture that recognises the significance of children (Nel 2000:9; 2001:13-14). The Bible affirms that the gospel is inclusive of all people, which includes youth (Nel 2001:14). The value and importance of youth are represented throughout scripture. One can, therefore, begin developing a theological articulation on the significance of children. In the Old Testament, there are explicit commands highlighting the need and importance of families raising children to know the story of God. The family setting was the primary locale for this tuition as it is families who should ultimately be responsible for the spiritual wellbeing and raising of children. The parent-child tutelage was however not one-sided from parent to child; instead, 
it was dialogical (Nel 2000:20). As one progresses to the New Testament, the importance of children is affirmed through the ministry of Jesus Christ, who through his words and actions explicitly demonstrated God's love and care for youth (Nel 2000:12).

When one contemplates the office of the career youth pastor, the Pauline texts of 1 Timothy 3 and Titus address the role of eldership regarding the spiritual oversight in the church. The youth pastor who is no different from the senior or lead pastor qualifies as an elder, except that the function is directed but is not limited to a specific category in the church, namely the youth. Ephesians 4 acknowledges the complexity of the church as a body with many parts, which would require a plurality of gifting and could lead one to assume a plurality of elders.

The Bible does indeed support the need and command to share the gospel with all people and is not limited to only the adult population. Furthermore, the Bible supports the need for a contextual ministry, in serving the widows, orphans, the poor and the marginalised. It does allow one the creativity to identify the ministry to youth also as a contextual ministry. Ministry in this sense is functional, which would adapt to the needs of the community and would further affirm the need for a plurality of elders.

\section{A cultural justification}

Culture is a broad term to address, although it is generally the world in which youth live. It is everything that affects the young person, but equally it is everything that the young person affects. Culture is more than cause and effect; it can often be described as a dance between two or more characters. Aspects ofculturalinfluenceareglobalisation, intergenerational ministry and the youth's openness to change. It is generally agreed that the age at which people are most receptive to the transformational power of Jesus Christ is during childhood and adolescence, and the effects of the youth culture play a significant role shaping the youth's response to the gospel (Jacober 2011:77; Nel \& Thesnaar 2006:93-95). It, therefore, makes complete sense to acknowledge the role of culture in shaping the worldview of youth and to prioritise the ministry to youth.

It is a negligent exercise to ignore the influence that the youth culture has on youth (cf. Weber 2015:5). One should also understand that youth, too, shape and influence youth culture. Mueller (2006:127) argues that culture acts as both a map and mirror, not only revealing the lived reality of youth but also mapping the direction that youth is heading. Yet culture, like youth, is not homogenous and consists of many subcultures existing of smaller unique groups within society (Nel 2000:8). Erwin (2010) explains that subcultures are:

formed within the context of the larger culture when individuals or groups encountered problems of status ... subcultures form when groups have difficulties achieving status within the normal, legitimate avenues of a dominant culture. (p. 53)
While culture has the power of creation or destruction, it is both inclusive and exclusive, welcoming and rejecting youth at the same time. Youth culture and its subcultures do not only affect the lives of youth but also the church as culture is no longer determined by race, culture, geography, religion or gender, which does threaten the church's identity and tradition (Nel \& Thesnaar 2006:93-95).

This raises the serious concern of generational differences and the need for intergenerational ministry, whereby the youth pastor is ideally suited for appropriate mediation. Ross (2012:142) defines an intergenerational ministry as 'bringing the various generations of the church family together within the core ministry activities of the church'. Intergenerational ministry is an intentional response from the church for integration and communal worship; it's what $\mathrm{Nel}$ (2000) refers to as an inclusive congregational approach. While an intergenerational ministry does acknowledge the need for age-specific ministry because of developmental needs, it raises the concern of the separation of the faith family and is intentional in ways of addressing the matter (Nel 2000:77; Roberto 2012:110). A lack of intergenerational ministry threatens the building-up of the local church (Nel 2000:63), the continued faith formation of the youth and the youth remaining at the church through their teenage years (Roberto 2012:107-109). It therefore becomes important to consider the need for dedicated and intentional focus to address an intergenerational agenda, usually through the office of the youth pastor.

\section{Adolescent identity formation}

Adolescence is not a cultural experience but is a legitimate life-stage and journey that is primarily focussed on identity formation (see Dean 2010:22-23). While it is reasonable to acknowledge the developmental processes of the adolescent as one that is complicated, various theories direct one to have a better understanding of the identity formation of the adolescent. It is accepted practice within practical theology to be interdisciplinary in order to illuminate its praxis, even more so in youth ministry when one considers the developmental process of the youth (cf. Jacober 2011:16, 20; Nel 2003b:68).

There are two aspects of developmental psychology that are paramount when considering youth, namely, the identity (Cloete 2012:74) and the individuation (Nel 2003a:161) of the youth. The challenges of growing up in a globalised world and the constant transforming family have a direct impact on the socialisation (Weber 2015:3-4) and individuation of the young person, which in turn has a direct bearing on the identity formation process of the youth (Elkind 1994:31-36). Individuation is the process whereby youth seek to become an autonomous individual by achieving an independence from their parents and is part of the process of identity formation ( $\mathrm{Nel} \mathrm{2003a:161).} \mathrm{It} \mathrm{is}$ during individuation that one is able to form one's selfconcept - how one perceives oneself - and self-esteem - the value youth place on themselves. 
Identity formation is not static as it is constantly adjusted to accommodate one's changing beliefs as the person interacts with his or her environment. Furthermore, identity is when the youth is able to master certain societal tasks and arrive at an occupation (Rice 1992:83). Identity formation is more than a journey and a process; it is the totality of oneself as expressed in the person's 'physical, sexual, social, vocational, moral, ideological, and moral identities' (Rice 1992:78). It therefore makes sense why Cloete (2012:74) and Weber (2015:4) argue that one cannot separate the youth's identity and the spiritual formation, as they are whole beings and not separate parts of a whole. Identity formation is the ability, therefore, to critically engage in and with life's existential questions, a meaning-making out of life.

It has been my contention to highlight the biblical story and mandate for specific ministry to youth by specific leaders. Furthermore, I have also attempted to highlight the difficulty that the youth may have to navigate through life and the/their need of someone who is knowledgeable of this journey. These reasons could, therefore, support the conceptual basis for the office of the career youth pastor and prepare the background for an empirical approach to either validate or nullify my opinion on the research problem.

\section{Research plan}

The research problem attempts to address the lack of theological articulation regarding the office of the career youth pastor by researching the following concepts:

1. The theological articulation of the office of the career youth pastor.

2. The rationalisation for the office of the career youth pastor.

3. The efficacy of the career youth pastor in youth ministry.

I performed structured qualitative interviews with 14 senior or lead pastors in churches as interviews remain the most common qualitative research method. Interviews were recorded and transcribed verbatim where themes were identified from the data. Because of time and budgetary constraints, the sample selected was from the BUSA in the provinces of Gauteng and the Western Cape. The BUSA has a total of 444 churches spread throughout Southern Africa. There are 29 churches with full-time youth pastors and 415 churches with volunteer youth leaders. The percentage of the sample interviewed were $24.3 \%$ and $1.7 \%$, respectively, of the total population of churches. The purposive sample was employed and was further refined into two lists of 7 pastors each by means of a random sample. The lists comprised pastors where the church has a full-time youth pastor and volunteer youth workers serving in the church. It was my opinion that the senior or lead pastor would possess the required knowledge for the interview and would either influence or shape the theology of the church or would be influenced and shaped by the theology of the church. Also, interviewing the youth pastor would be biased in favour of the research and because not all churches have full-time youth pastors, the results would not be generalisable.

\section{Discussion}

\section{The theological articulation of the office of the career youth pastor}

As much as $92 \%$ of the respondents defined youth ministry as a specific and focussed ministry to children, youth and young adults. Evangelism remained a priority where $50 \%$ said it is a means to introduce youth to Christ and $21 \%$ said it's a place of faith formation, $28 \%$ stated the youth pastor is an elder with pastoral oversight of youth ministry, $7 \%$ stated that the youth pastor should have a relationship with Christ and 50\% indicated the youth pastor as task-oriented in areas of pastoral oversight.

\section{The rationalisation for the office of the career youth pastor}

Seventy-two per cent of the respondents stated there is no biblical evidence for the youth pastor; however, 50\% said that the Pauline texts reveal biblical evidence for pastoring; $50 \%$ required formal theological qualifications and $14 \%$ with additional qualifications in the social sciences; $78 \%$ required soft skills such as teaching, administration, a love for youth, leadership skills and biblical knowledge; 85\% stated that life experience is beneficial but not compulsory; $14 \%$ were explicit of a relationship with Christ and a call to youth ministry; $14 \%$ argued for a couple ministry for gender-specific needs; $14 \%$ stated that it is because of financial reasons that there is no youth pastor; $35 \%$ argued that because of a distinct youth culture there is a need for specific intergenerational ministry; $14 \%$ said that culture matters and the youth pastor should be knowledgeable regarding youth culture; and $72 \%$ said the youth pastor should be knowledgeable about youth developmental processes.

\section{The efficacy of the career youth pastor in youth ministry}

Fifty-seven per cent of the respondents said the primary responsibility of the youth pastor is pastoring, which would include caring, nurturing and counselling; $42 \%$ argued for task-oriented responsibilities, namely, programming, mission and evangelism, preaching, family ministry and translating the church vision to youth; $64 \%$ felt that the youth pastor should be a young person under 35 years of age and $72 \%$ felt that a career in youth ministry is dependent on the ability to relate to youth; $14 \%$ argued that there is no evidence of lifetime career in youth ministry while $35 \%$ felt it is possible, however, the ability to relate to youth is the major determiner; and $72 \%$ stated that the youth pastor should be entrepreneurial in creating meaningful ministry with youth which usually extends beyond the formal structures of the church.

\section{Key findings from the empirical research}

The findings of this particular research are only applicable to BUSA churches in the provinces of Gauteng and the Western Cape as the research has been limited to these provinces. 
It is, however, possible that the findings may be relevant to BUSA churches in other geographical areas. Further research on this matter is required to corroborate the findings with a broader community.

\section{The agency of youth ministry in the church}

Youth ministry is defined as an age-appropriate ministry to children, youth and young adults. It is characterised by the completion of assigned tasks and responsibilities usually concentrated on the outreach and evangelism of youth; teaching and discipling of youth to maturity in faith in Jesus Christ; familiarising the youth with the church vision, polity and successful integration of the youth into the church; partnering with families and parents by being a support and offering skills in parenting; and preparing youth for civic responsibilities. The ministry to youth remained the responsibility of the youth ministry and youth pastor and seldom extended to the rest of the church. There was no clear distinction between the definition and the purpose of youth ministry as both were described by similar tasks and responsibilities. There is no clearly articulated model, approach, intentional theological articulation or reflection concerning the praxis of youth ministry as the focus remains one that is task-orientated.

\section{Defining the youth pastor}

The responsibility of the youth pastor, while considered an elder in the church, is directed but not limited towards the youth. Similarly to the youth ministry, the youth pastor was defined by tasks and responsibilities assigned by the church. These tasks were similar to the tasks required in youth ministry; however, included in these tasks are the shepherding and pastoring of youth. Furthermore, the youth pastor is expected to be knowledgeable on all matters relating to youth culture and youth developmental processes. Similarly to youth ministry, there remains little to no theological reflection when attempting to define the youth pastor as it is reduced to being task-orientated, and no theological reflection is required or expected.

\section{Qualifications of the youth pastor}

Qualifications have been listed as formal and informal. Formal qualifications include any theological training from a seminary or university. While theological qualifications are desirable, it was not considered mandatory by all respondents. If formal qualifications are required, it is also expected of the youth pastor to pursue further studies in the social sciences. Informal qualifications include any life or ministerial experience, the ability to work with different people and a good reputation among the congregants. There was no mention made of any charismatic gifting required of the youth pastor. The youth pastor should be someone who has a relationship with Jesus Christ, is called to youth ministry and has a love for youth. Furthermore, the youth pastor should qualify as an elder according to the Pastoral Epistles in 1 Timothy 3 and Titus.

\section{Office of the youth pastor}

The responsibilities assigned to the office of the youth pastor were similar to the youth ministry and pastor, namely the completion of assigned tasks and responsibilities. The youth pastor is solely responsible for creating a meaningful ministry with the youth, and often this meaningfulness is derived from time spent with the youth that exceeds the dedicated formal time of youth ministry at the church. It also remains the responsibility of the youth pastor to facilitate and implement the church vision in the youth ministry and ultimately integrate the youth into the church. The church often becomes hands off in the ministry towards youth and delegates all responsibility towards the youth pastor and the youth ministry. Family ministry also remains a priority for the youth pastor. There remains little theological reflection required of the youth pastor except for the completion of tasks.

\section{Justifications for the career youth pastor}

There remains very little justification for a career youth pastor. When discussing areas of biblical and cultural support for the career youth pastor, the respondents were generally vague. It was argued that there is no biblical evidence for ministry to youth and that of the youth pastor. There were, however, general biblical accounts used to support ministry to youth, for example, the command in Deuteronomy 6 on teaching children about God, the ministry of Jesus towards children, the mentoring passages of Paul and Barnabas, Paul and Timothy and the biblical declaration that the gospel is for all people.

The youth culture was not considered as a factor by all respondents when determining the need for a career youth pastor. It was also felt that the gospel stands above youth culture and should not be influenced by it. It did, however, remain the task of the youth pastor to be knowledgeable about youth culture in order to address the prevalent differences of culture within the church in order to minimise the cultural divide between the youth and adults for an intergenerational ministry.

\section{Career in youth ministry}

While it is possible to have a career in youth ministry there remains little evidence of such practitioners. There are several factors that determine the possibility to have a career in youth ministry, such as the ability to relate to youth and the age and life-stage of the youth pastor. While the youth pastor should not be too young as this would rob the youth pastor of any required experience, the youth pastor should also not be too old as this would inevitably prohibit any means of being able to relate to the youth. The youth pastor should be aged in the mid-twenties to mid-thirties, implying an exit from youth ministry. There is still, however, a general perception that the youth pastor will eventually gain enough experience, or, because of lifestyle changes, become a senior pastor of the church. The promotion to the senior ministry was not because of youth ministry being a stepping-stone but because, logistically, it is not possible to have a career in youth ministry. 


\section{Re-conceptualisation of the office of the youth pastor}

The article has raised and affirmed the concern that there is indeed a lack of theological articulation regarding the office of the career youth pastor in the BUSA. Furthermore, the article has also identified that there is a misunderstanding regarding the purpose and definition of youth ministry, and that unfortunately youth ministry, and also that of the office of the career youth pastor, is minimised to task-related matters and lacks any serious theological reflection. The results of a lack of theological articulation concerning the office of the career youth pastor and youth ministry perpetuate an ineffective youth ministry and fail to take serious the lived realities of youth (Jacober 2011:28).

The re-conceptualising of the office of the career youth pastor has to take additional factors into consideration that was not covered in this study but has been raised by the respondents. Firstly, an area of further research should address the vast cultural differences in the South African context when addressing the office of the career youth pastor (cf. Black 1991:134; Nel \& Thesnaar 2006). Secondly, further research should also address the various aspects of remuneration of the career youth pastor (cf. Kageler 2004). Thirdly, part of the dilemma is because of the paucity of literature in the area of youth ministry in the South African context (cf. Weber 2015). Finally, further research should investigate the implications of a lack of theological articulation in youth ministry and more specifically that of the career youth pastor.

\section{Conclusion}

The aim of the article was to address the lack of theological articulation for the office of the career youth pastor in the BUSA. The problem raised in the article was addressed and supported by theoretical and empirical research to investigate the validity of the office of the career youth pastor by addressing the theological reasoning along the lines of a biblical foundation, a cultural justification and adolescent identity formation. The article has identified that there is indeed a lack of theological articulation concerning the office of the career youth pastor and a need for the re-conceptualising of the office of the career youth pastor. Researching the office of the career youth pastor in a South African context is a new endeavour, and there is a need for further empirical research in this vital area of youth ministry. We shall be able to better address, through further research, the re-conceptualisation of the office of the career youth pastor that is appropriate to the South African context (Nel 2003b:75-76).

\section{Acknowledgements Competing interests}

The authors declare that they have no financial or personal relationships which may have inappropriately influenced them in writing this article.

\section{Authors' contributions}

M.N. and R.D. served in a supervising capacity, guiding, editing and directing the work.

\section{References}

Black, W., 1991, An introduction to youth ministry, Broadman Press, Nashville, TN.

Ciarrochi, J. \& Heaven, P.C.L., 2012, 'Religious values and the development of trait hope and self-esteem in adolescents', Journal for the Scientific Study of Religion 51(4), 676-688. https://doi.org/10.1111/j.1468-5906.2012.01675.x

Clark, C., 2001, 'The missional approach to youth ministry', in M.H. Senter III (ed.), Four views of youth ministry and the church, pp. 77-96, Zondervan, Grand Rapids, MI.

Cloete, A., 2012, 'Spiritual formation as focus of youth ministry', G.V. Brand (ed.), Dutch Reformed Theological Journal 53(3-4), 70-77. https://doi.org/10.5952/533-4-250

Dean, K.C., 2010, OMG: A youth ministry handbook, Abingdon Press, Nashville, TN.

Dean, K.C., 2011, 'Introduction', in A. Root \& K.C. Dean (eds.), The theological turn in youth ministry, pp. 13-24, IVP, Downers Grove, IL.

Elkind, D., 1994, Ties that stress: The new family imbalance, Harvard University Press, London.

Erwin, P., 2010, A critical approach to youth culture: Its influences and implications for ministry, Zondervan, Grand Rapids, MI.

Jacober, A.E., 2011, The adolescent journey: An interdisciplinary approach to practical youth ministry, IVP Books, Downers Grove, IL.

Kageler, L., 2004, 'A global youth pastor salary survey: Sociological and ecclesiological perspectives', S. Griffiths (ed.), Journal of Youth Ministry 2(2), 75-97.

Mueller, W., 2006, Engaging the soul of youth culture: Bridging teen worldviews and Christian truth, IVP, Downers Grove, IL.

Nel, M., 2000, Youth ministry: An inclusive congregational approach, Malan Nel, Pretoria.

Nel, M., 2001, 'The inclusive congregational approach to youth ministry', M.H. Senter III (ed.), Four views of youth ministry and the church, pp. 1-22, Zondervan, Grand Rapids, MI.

Nel, M., 2003a, 'Youth ministry: The challenge of individuation', Practical Theology in SA - Praktiese Teologie in SA 18(1), 151-196.

Nel, M., 2003b, 'Youth ministry as a practical theology: Making a case for youth ministry as an academic discipline', S. Griffiths (ed.), Journal of Youth and Theology 2(1), 68-84. https://doi.org/10.1163/24055093-90000205

Nel, M., 2005, 'Public pastoral leaders: The purpose of theological training', In die Skriflig/In Luce Verbi 39(3), 441-462. https://doi.org/10.4102/ids.v39i3.397

Nel, M. \& Thesnaar, C., 2006, 'Theologically informed and culturally relevant youth ministry', Practical Theology in South Africa 21(2), 90-112.

Rice, F.P., 1992, The adolescent: Development, relationships and culture, 7th edn., Allyn and Bacon, Boston, MA.

Roberto, J., 2012, 'Our future is intergenerational', Christian Education Journal 9(1), 105-120.

Root, A. \& Dean, K.C., 2011, The theological turn in youth ministry, IVP, Downers Grove, IL.

Ross, C.M., 2012, 'Four congregations that practice intergenerationality', Christian Education Journal 9(1), 135-147.

Senter, III, M.H., 2001, 'The strategic approach to youth ministry', in M.H. Senter, III (ed.), Four views of youth ministry and the church, pp. 113-135, Zondervan, Grand Rapids, MI.

Statistics of South Africa, 2012, Census 2011 provinces at a glance, Report No. 03-0143, Statistics South Africa, viewed 16 March 2016, from http://www.statssa.gov. $\mathrm{za} /$ census/census_2011/census_products/Provinces $\% 20 \mathrm{at} \% 20 \mathrm{a} \% 20 \mathrm{glance} \% 20$ $16 \% 20$ Nov $\% 202012 \% 20$ corrected.pdf

Strommen, M., Jones, K.E. \& Rahn, D., 2001, Youth ministry that transforms: A comprehensive analysis of the hopes, frustrations, and effectiveness of today's youth workers, Zondervan, Grand Rapids, MI.

Strong, P., 2014, 'Effective youth ministry: Embracing a family-orientated approach', Die Skriflig 48(1), Art. \#1715, 1-8. https://doi.org/10.4102/ids.v48i1.1715

The Commonwealth, 2013, South African President launches Commonwealth youth worker conference, viewed 30 August 2013, from http://www.thecommonwealth. org/news/253897/200313youthworkerconference.htm

The Presidency, 2013, 'Welcome Address delivered by the NYDA Chief Executive Officer (CEO) Steven Ngobeni on behalf of Minister in The Presidency for performance and monitoring and evaluation', Collins Chabane at the Commonwealth Conference on monitoring and evaluation', Collins Chabane at the Commonwealth Conference on
Education and Training of Youth Workers, University of South Africa, Pretoria, March 17, 2013.

The Republic of South Africa, National Youth Development Agency (NYDA) Act (NYP) No 54 2008, viewed 18 June 2014, from http://www.thepresidency.gov.za/docs/ nyda_act.pdf

Weber, S., 2015, 'A (South) African voice on youth ministry research: Powerful or powerless?', HTS Teologiese Studies/Theological Studies 71(2), Art. \#2973, 1-6. https://doi.org/10.4102/hts.v71i2.2973 